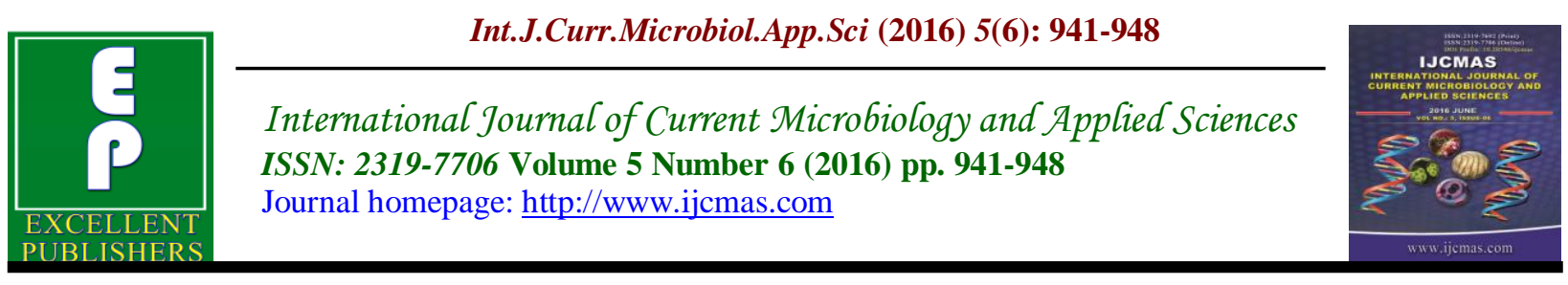

Original Research Article http://dx.doi.org/10.20546/ijcmas.2016.506.101

\title{
Detection and Molecular Characterization of Listeria species in 'Wara', A West African Local Cheese Sold in Ekiti State
}

\author{
Oyinloye, Josiah Mofoluwaso Adedeji* \\ Afe Babalola University, Biological Sciences Department, PMB 5454, \\ Ado Ekiti, Ekiti State, Nigeria \\ *Corresponding author
}

\begin{abstract}
A B S T R A C T
Keywords

Cheese,

Wara,

RTE,

L. monocytogenes.

Article Info

Accepted:

26 April 2016

Available Online:

10 June 2016

Bacterial analysis of 116 soft cheeses 'wara', a ready-to-eat (RTE) product of fresh milk, bought in major markets of Ekiti State was done. Molecular analysis of isolates was done by coupling PCR to the DNA sequencing of Listeria $16 \mathrm{~S}$ rRNA gene. Results yielded 459 bacteria with $78 \%$ positive to Listeria. Six different species of Listeria were identified with $L$. monocytogenes occurring at $12.4 \%$ of total Listeria. Ampiclox (ampicillin/cloxacillin) and amoxicillin showed very weak potency against all isolates at $10 \%$ and $11 \%$ respectively; while ciprofloxacin and septrin (co-trimoxazole) showed high potency at 84.95 and $82.6 \%$ respectively. The status of the RTE soft cheese 'wara' as sold in these is non-hygienic, hence microbiologically unsafe for consumption.
\end{abstract}

\section{Introduction}

The average food consumer seeks to improve his or her everyday diet based on personal or health reasons, thus, a desire for a healthy, low in fat, calories and sodium but high in fibre and of great taste are ever on the request in the market places. Ready-toeat (RTE) foods come in handy with the fast and ever moving nature of man's life, thus, consumers demand for food products that have a more natural content than chemical content. Most of these natural food products require good storage system and a high level of hygiene to prevent spoilage and contamination.
The most common storage system for these foods is by refrigeration, but with the availability of microorganisms capable of surviving the refrigeration system, knowledge of the occurrence and distribution of these microbes in RTE foods and in the environment is needful.

Wara, a local unripened cheese consumed in several parts of West Africa, is prepared by coagulating fresh cow milk with the leaf extract of the Sodom apple (Calotropis procera) or pawpaw (Carica papaya). An alternative coagulant, "lemon juice" was 
introduced into the processing of 'wara' soft cheese by Adetunji et al. (2007) and was found to reduce the microbial load. Several microorganisms have been incriminated to be present in raw milk and milk products (cheese and yoghurt) that are of public health importance. These microorganisms are capable of causing food borne illnesses after ingestion and these organisms range from viruses, rickettsia, bacteria, protozoan and parasitic organisms to their toxins (Kaplan and Bertagna, 1955). Among these bacteria, Escherichia coli and $L$. monocytogenes are important indicators of contamination of milk and milk products, thus resulting in coliform infections; which presents as gastroenteritis and listeriosis respectively.

Listeria monocytogenes, the source of the human disease listeriosis, is a ubiquitous food-borne pathogen, identified decades ago to cause food poisoning outbreaks with high mortality rate. These bacteria are short, Gram positive rods, facultative anaerobes, motile by one to five peritrichous flagella, with both psychotropic and mesophilic features (Gray and Killinger, 1966; Seeliger and Jones, 1986). Today, L. monocytogenes is considered to be one of the most important agents of food-borne disease. Possible explanations for the emergence of human food-borne listeriosis as a major public health concern include major changes in food production, processing and distribution, increased use of refrigeration as a primary preservation means for foods, changes in the eating habits of people, particularly towards convenience and RTE foods, and an increase in the number of people considered to be at high risk for the disease (elderly, pregnant women, newborns, immunocompromised) (OIE, 2005). Between the years 2011 and 2014, different outbreaks due L. monocytogenes was reported by the Centre for Disease Control and Prevention (CDC) involving multistates in the United States, which recorded mortality rates at $22.5 \%, 18.2 \%$, $33.3 \%$, and $20 \%$ respectively. Outbreak of listeriosis has been linked to the consumption of cheese in many parts of the world (Gellin and Broome, 1989; Goulet et al., 2001; Makino et al., 2005; Wehr, 1989). In Nigeria, several reports on the occurrence of L. monocytogenes have been made in food products such as meat (beef, mutton, pork, poultry), farm produce such as cabbage and lettuce, RTE foods such as vegetable salads, cereal-based beverage called 'kunnu', soil samples from abattoir, smoked fish from market places, critical control points of local cheese and yoghurt production, and faecal samples of some ruminants (Salihu et al. 2008; Nwachukwu et al., 2009; Umeh and Okpokwasili, 2009; Ikeh et al., 2010; Adetunji and Arigbede, 2011; Ieren et al., 2013; Eruteyah et al., 2014). The contamination of raw and pasteurized milk by these microorganisms suggests the possibility of their transmission to humans through consumption of milk products. Human infection is more devastating in immunosuppressed individuals; pregnant women, infants, geriatrics, HIV-AIDS patients, etc. Pregnant women may experience abortion, stillbirth, premature birth or septicemia in the newborn. The elderly and infants suffer from meningitis, meningoencephalitis or, less frequently, septicaemia (Acha and Szyfres, 2003).

Today, life stock farming (especially ruminants), is a promising venture which can provide income, employment, food, farm energy, manure, fuel and transport to the average Nigerian, and it is gaining more support by government policies. These animals may shed these bacteria in milk over long periods without showing any symptoms of the disease (Low and Donachie, 1997), and spoiled silage has been identified as the principal source of 
infection in these animals (Vazquez-Bolland et al., 1990; Low and Donachie, 1997; Weidmann, 2003). Most bacterial pathogens associated with human food poisoning often originate from farm, vegetation, soil, or animal products.

This study therefore investigated the occurrence of L. monocytogenes and other species and their antimicrobial profiles in RTE locally marketed 'wara' in five known towns of Ekiti State, South-Western Nigeria.

\section{Materials and Methods}

\section{Sample Collection and Laboratory Analysis}

A total of 116 soft cheese products were bought from Fulani women marketers in the RTE state from five different towns of Ekiti State; Ifaki (23), Otun (25), Ado (30), Ikere (22) and Ijan (16). These samples were stored on ice and transported to the laboratory for further analysis.

The FDA bacteriological and analytical method (BAM) (Hitchins, 2001) was employed; Analytical portions (25g) was enriched for Listeria species in $225 \mathrm{ml}$ of selective enrichment broth, University of Vermont Medium Modified Listeria Enrichment Broth (Alpha Biosciences, USA), with selective agent (Oxoid, UK) after 4 hours of incubation, and then subsequent incubation at $35^{\circ} \mathrm{C}$ for 44 hours. The enrichment culture was streaked at 24 and 48 hours on Brilliance Listeria agar with differential and selective supplements (Oxoid, UK). Blue-green colonies on media that expressed Gram positive coccobacilli on Gram staining were presumed to be Listeria species.

\section{Biochemical Differentiation}

This was done in reference to Collins et al., (1991). More presumptive identification was done using the Oxoid Biochemical Identification System, OBIS mono kit (ID0600) (Oxoid, UK) in which isolates showing no colouration (purple colour) in reaction with the reagents is presumed $L$. monocytogenes.

\section{Molecular Studies}

This study was done by coupling PCR to the DNA sequencing analysis of Listeria $16 \mathrm{~S}$ rRNA genes (Wang et al., 1992; Manzano et al., 2000). Genomic DNA was extracted using QIAamp DNA mini kit (250) cat no 51306. Polymerase Chain Reaction (PCR) was performed using 27F (5AGAGTTTGATCMTGGCTCAG -3') and 1525R (5- AAGGAGGTGWTCC ARCCGCA -3') universal primers and PCR protocols were performed as described by Bubert et al. (1992). PCR procedures were as follows: 36 cycles, each at $94^{\circ} \mathrm{C}$ for 30 seconds, $56^{\circ} \mathrm{C}$ for 30 seconds, and $72^{\circ} \mathrm{C}$ for 7 minutes.

The end products were separated on a $1.5 \%$ agarose gel which was stained with ethidium bromide. PCR products were visualized under UV light. The amplicons were subjected to sequencing reactions using BigDye Terminator v3.1 Cycle Sequencing Kit. The products were loaded unto 3130xl Genetic Analyzer (Applied Biosystems), and molecular sequences were identified by a combination of BLAST and FASTA (Donkor et al., 2014).

\section{Phenotypic Expression of Pathogenic Traits}

The production of lecithinase was demonstrated on the medium (Brilliance Listeria agar with the differential supplements). Production of an opaque white halo around the colony confirms the presence of the enzyme. The production of listeriolysin was demonstrated on 5\% sheep blood agar. 


\section{Antibiotic Susceptibility Testing}

Using the Kirby-Bauer disc diffusion method as recommended by the Clinical Laboratory standards Institute (CLSI, 2013). The prevailing common antibiotics were employed; Pefloxacin (10g), Gentamycin (10g), Ampiclox (Ampicillin/cloxacillin, 30g), Zinnacef (cefuroxime, 20g), Amoxacillin (30g), Rocephin (ceftriaxone, 25g), Ciprofloxacin (10g), Streptomycin (30g), Septrin (cotrimoxazole, 30g), and Erythromycin (10g).

\section{Results and Discussion}

A total of four hundred and fifty nine (459) isolates were gotten from 116 wara samples sold in the markets in the RTE state. The prevalence of positive samples to Listeria was $78 \%$. Listeria species identified are $L$. innocua (19.4\%), L. rocourtiae (12.2\%), L. monocytogenes $(12.4 \%)$, L. grayi $(8.5 \%)$, L. fleischmannii (17.7\%), and Listeria species (7.8\%) (Figure 1). The distribution of the isolates per towns of samples collection is detailed in Table 1. Listeria ivanovii was not isolated in this study. Of the Listeria species isolated, Listeria innocua had the highest occurrence at $19.4 \%$, followed by $L$. fleischmannii, $L$. monocytogenes, $L$. rocourtiae, L. grayi and Listeria species at
$17.7 \%, 12.4 \%, 12.2 \%, 8.5 \%$ and $7.8 \%$ respectively. In all bacterial isolates however, Brochothrix species occurred the most at $22.0 \%$. Samples from Ifaki town market recorded the highest occurrence of Listeria at 91 (25.4\%), while the least was recorded in samples from Ijan town market at $34(9.5 \%)$. The known pathogenic isolate, L. monocytogenes, was observed in samples from other towns except in Ijan town market and was observed to be highest in Otun town market at $19(22.9 \%)$.

The expression of lecithinase production was observed in all isolates of $L$. monocytogenes, while 56 (98.2\%) expressed a thin line of haemolysis on blood agar. Other isolates were negative to both tests except $L$. innocua, showing a wide line of haemolysis on blood agar (Table 2).

Antibiotic susceptibility test results reveals a $100 \%$ resistance in all isolates against ampiclox (ampicillin/cloxacillin) and amoxicillin, $90 \%$ and $89 \%$ resistance in all isolates against zinnacef (cefuroxime) and rocephin (ceftriaxone) respectively. In all isolates, ciprofloxacin showed the highest potency at $84.9 \%$, closely followed by septrin (co-trimoxazole) at $82.6 \%$ (Figure 2).

Table.1 Distribution of Isolates per Town

\begin{tabular}{|l|l|l|l|l|l|l|l|}
\hline $\begin{array}{l}\text { Towns } \\
(\mathrm{n})\end{array}$ & $\begin{array}{l}\text { Brochothrix } \\
\text { sp. }\end{array}$ & $\begin{array}{l}\text { L. } \\
\text { innocua }\end{array}$ & $\begin{array}{l}\text { L. } \\
\text { rocourtiae }\end{array}$ & $\begin{array}{l}\text { L. } \\
\text { monocytogenes }\end{array}$ & $\begin{array}{l}\text { L. } \\
\text { grayi }\end{array}$ & $\begin{array}{l}\text { L. } \\
\text { fleischmanni }\end{array}$ & $\begin{array}{l}\text { Uncultured } \\
\text { Listeria } \\
\text { spp }\end{array}$ \\
\hline Ado (30) & 30 & 22 & 13 & 16 & 0 & 18 & 07 \\
\hline Ijan (16) & 12 & 07 & 07 & 0 & 0 & 09 & 11 \\
\hline Otun (25) & 24 & 21 & 16 & 19 & 11 & 16 & 0 \\
\hline Ikere (22) & 12 & 21 & 07 & 11 & 08 & 22 & 05 \\
\hline Ifaki (23) & 23 & 18 & 13 & 11 & 20 & 16 & 13 \\
\hline $\begin{array}{l}\text { Total } \\
\text { (116) }\end{array}$ & $\mathbf{1 0 1}$ & $\mathbf{8 9}$ & $\mathbf{5 6}$ & $\mathbf{5 7}$ & $\mathbf{3 9}$ & $\mathbf{8 1}$ & $\mathbf{3 6}$ \\
\hline
\end{tabular}


Table.2 Pathogenic Trait Expression

\begin{tabular}{|l|c|c|}
\hline Isolates & Lecithinase & Haemolysis \\
\hline Brochothrix sp. & - & - \\
\hline L. innocua & - & +++ \\
\hline L. rocourtiae & - & - \\
\hline L. monocytogenes & ++ & + \\
\hline L. grayi & - & - \\
\hline L. fleischmannii & - & - \\
\hline Uncultured Listeria spp & - & - \\
\hline
\end{tabular}

Figure.1 Overall Occurrence of Isolates

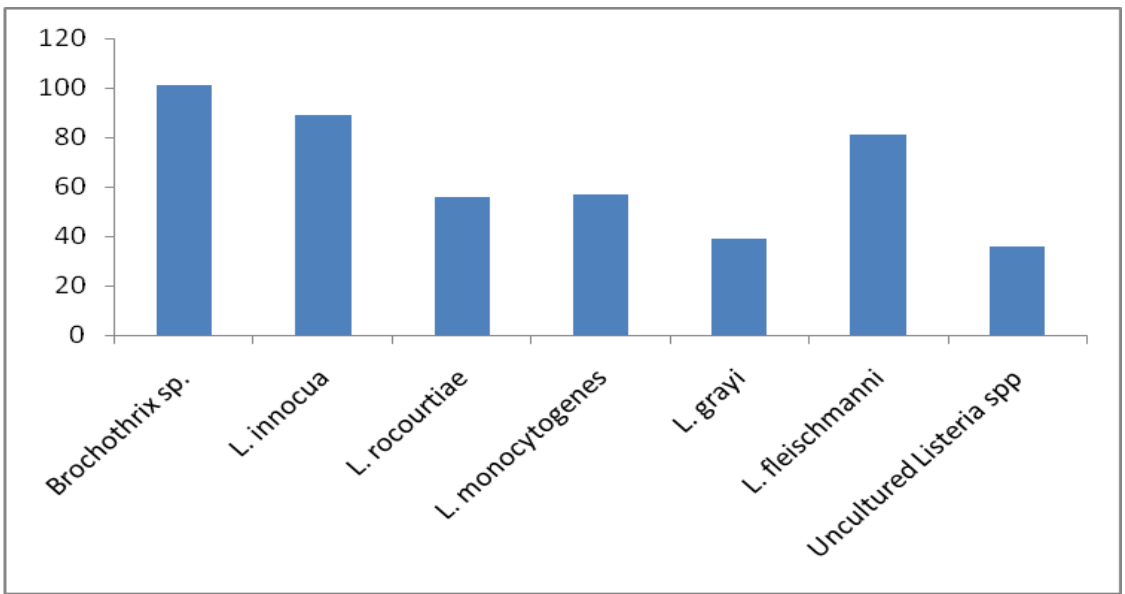

Figure.2 Overall Percentage Susceptibility to Antibiotics in all Isolates

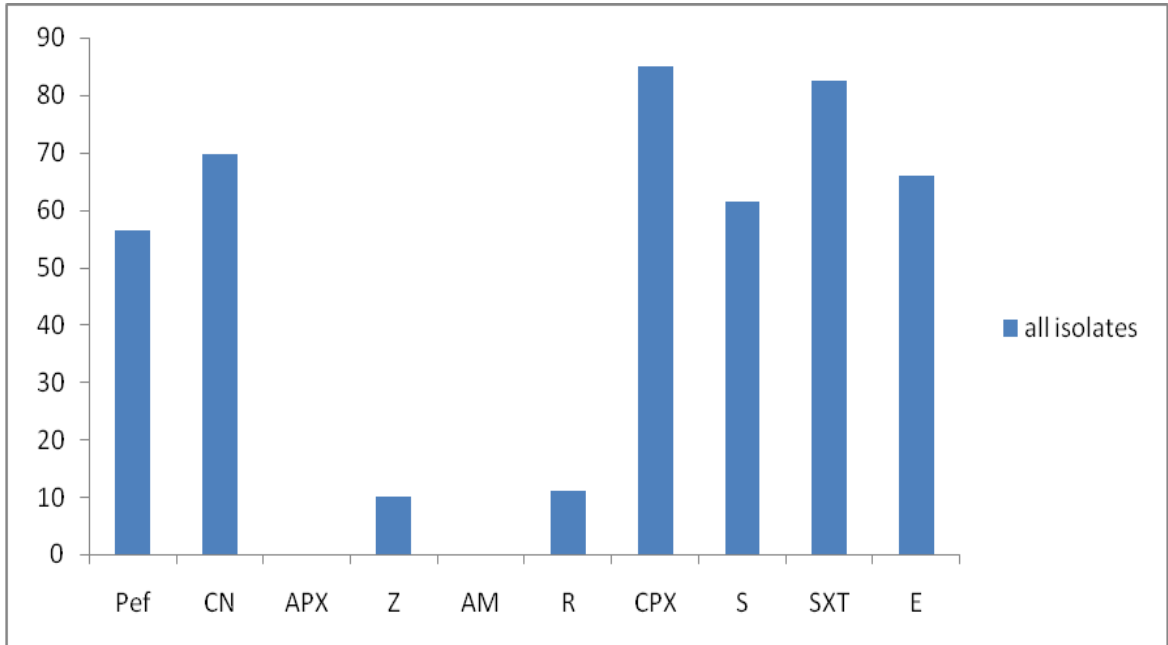

Key: Pef - pefloxacin, CN - gentamycin, APX - ampiclox, Z - zinnacef, AMX - amoxicillin, R rocephin, CPX - ciprofloxacin, $\mathrm{S}$ - streptomycin, SXT - septrin, E - erythromycin 
From the study, the local cheese in its RTE state, sold in the markets sampled is contaminated with indicator organisms, which makes it unhealthy for food, especially by those classified to be at high risk of infection. It has been reported by different works that L. monocytogenes has the ability to survive the manufacture and storage conditions of several cheeses (Adetunji and Arigbede, 2011; Anonymous, 2006; Manfreda et al., 2005; Carminati et al., 2004; Erkmen, 2001; Buazzi et al., 1992; Yousef and Marth, 1990). Emphasis have been made that, the contamination of cheese or end-products with $L$. monocytogenes is most likely due to; contamination during the ripening stage (Pak et al., 2002), post process contamination from environmental sources, cross-contamination in the dairy plant and/or retail stores, inadequate processing (FAO/WHO, 2004; Pak et al., 2002; Rudolf and Seigfried, 2001; Sagun et al., 2001) and colonization in retail stores (Sergelus et al., 1997). The high occurrence of these organisms in wara depicts the hygiene level of either the source (milk), process of production, storage facility or even the marketers. Adetunji and Arigbede (2011), reported the occurrence of Listeria through the processing line and in the finished product at significant levels $(\mathrm{p}<0.05)$ above international standards. Identified Listeria species were $71 \%$ of all isolates in this study, which corroborates reports from other countries about foods of animal origin (Ikeh et al., 2010; Choi et al., 2001; Miettinen et al., 2001; Hassan et al., 2001).

The antibiotic susceptibility test of the isolates showed that Listeria monocytogenes is susceptible to ciprofloxacin, septrin (cotrimoxazole), gentamycin, erythromycin, streptomycin and pefloxacin but resistant to ampicillin/cloxacillin, amoxicillin, ceftriaxone and cefuroxime. This finding is similar to reports of Yakubu et al., (2012) in Sokoto State and Nwachukwu et al., (2009) in Abia State. However, conflicting reports to that of this study was reported by Umeh and Okpokwasili (2009), showing Listeria monocytogenes to be sensitive to erythromycin, ampicillin, cotrimoxazole and amoxicillin. The resistance to the third generation cephalosporin may be due to its use in the selective isolation of species in this genus. Resistance could also be attributed to the irrational use of the antibiotics in veterinary medicine in the study area.

In conclusion, this study established the occurrence of L. monocytogenes and other species in wara in the RTE state from markets in Ekiti State. This brings to light the poor handling and unhygienic level of this product for consumption, especially by persons classified as high risk.

\section{References}

Acha, P.N., Szyfres, B. 2003. Zoonoses and communicable diseases common to man and animals. In: Bacterioses and mycoses. Pan American Health Organization (PAHO) Scientific and Technical Publication, 3rd edition. Washington DC: No. 580, Pp 168-179.

Adetunji Victoria, O., Arigbede Mary, I. 2011. Occurrence of E. coli $\mathrm{O} 157: \mathrm{H} 7$ and Listeria monocytogenes and Identification of Hazard Analysis Critical Control Points (HACCPs) in Production Operations of a Typical Tropic Cheese 'Wara' and Yoghurt. Pakistan J. Nutri., 10 (8): 796-804.

Adetunji, V.O., D.O. Alonge, R.K. Singh, J. Chen. 2007. Production of wara, a West African soft cheese using lemon juice as coagulant (LWT). J. Chem. Swiss Soc. Food Sci. Technol., 41: 331-336.

Anonymous. 2006. Brining 101-chapter 1 the 
why and what of brining.

Buazzi, M.M., M.E. Johnson and E.H. Marth. 1992. Fate of Listeria monocytogenes during the manufacture of Mozzarella cheese. J. Food Prot., 55: 80-83.

Bubert, A., Kohler, S., Goebel, W. 1992. The homologous and heterologous regions within the iap gene allow genus- and species-specific identification of Listeria spp. by polymerase chain reaction. Appl. Environ. Microbiol. 58, 2625-2632.

Carminati, D., M. Gatti, B. Bonvini, E. Neviani and G. Mucchetti. 2004. Highpressure processing of Gorgonzola cheese: Influence on Listeria monocytogenes inactivation and on sensory characteristics. J. Food Prot., 67: 1671-1675.

Choi, Y.C., Cho, S.Y., Park, B.K., Chung, D.H., Oh, D.H. 2001. Incidence and characterization of Listeria species from foods available in Korea. J. Food Prot. 6: 554-558.

Erkmen, O. 2001. Survival of Listeria monocytogenes during the manufacture and ripening of Turkish white cheese. Nahrung/Food, 45: 5558.

Food and Agriculture Organization/World Health Organization (FAO/WHO), 2004. Risk assessment of Listeria monocytogenes in Ready-to-Eat foods. Technical Reports: Microbiological Risk Assessment Series 5, Geneva.

Gellin, B.G., and C.V. Broome. 1989. Listeriosis. J. Am. Med. Assoc., 261: 1313-1320.

Goulet, V., H. De Valk, O. Pierre, F. Stainer, J. Roccourt and V. Vaillant. 2001. Effect of prevention measures on incidence of human listeriosis, France, 1987- 1997. Emerg. Infect. Dis., 7: 983-989.

Hassan, Z., Purwati, E., Radu, S., Rahim, R.A., Rusul, G. 2001. Prevalence of Listeria species and Listeria monocytogenes in meat and fermented fish in Malaysia. Southeast Asian J.
Trop. Med. Public Health, 32: 402407.

Hitchins, A.D. 2001. Chapter 10: Listeria monocytogenes US Food and Drug Administration Bacteriological Analytical Manual (online)

Ikeh, M.A.C., Obi, S.K.C., Ezeasor, D.N., Ezeonu, I.M., and Moneke, A.N. 2010. Incidence and pathogenicity profile of Listeria sp. isolated from food and environmental samples in Nsukka, Nigeria. African J. Biotechnol., 9(30): 4776-4782

Kaplan, M.M. and P. Bertagna. 1955. Bulletin, World Health Organisation, 13: 829.

Low, J.C., and Donachie, W. 1997. A review of Listeria monocytogenes and listeriosis. Vet. J., 153, 9-29.

Makino, S.I., K. Kawamato, K. Takeshi, Y. Okada, M. Yamasaki and S. Yamamoto. 2005. An outbreak of food-borne listeriosis in Japan during 2001. Int. J. Food Microbiol., 102: 189-196.

Manfreda, G., A. Acesare, S. Stella, M. Cozzi and C. Cantoni. 2005. Occurrence and ribotypes of Listeria monocytogenes in Gorgonzola cheeses. Int. J. Food Microbiol., 102: 287-293.

Miettinen, M.K., Palmu, L,. Bjorkroth, K.J., Korkeala, H. 2001. Prevalence of Listeria monocytogenes in broilers at the abattoir. J. Food Prot. 64: 994-996.

Nwachukwu, N.C, Orji, F.A., and Amaike, J.I. 2009. Isolation and Characterization of Listeria monocytogenes from Kunu, a Locally Produced Beaverage Marketed in Different Markets in Abia State of Nigeria. Australian J. Basic and Appl. Sci., 3(4): 4432-4436.

Pak, S.L., U. Spahr, T. Jemmi and M.D. Salman. 2002. Risk factors for Listeria monocytogenes contamination of dairy products in Switzerland 1990-1999. Prev. Vet. J., 53: 55-65.

Rudolf, M. and S. Seigfried. 2001. High incidence of Listeria monocytogenes in European red smear cheese. Int. J. Food Microbiol., 63: 91-98. 
Sagun, E., Y.C. Sancak, O. Isleyici and K. Ekici. 2001. The presence and prevalence of Listeria spp in milk and herby cheese in and around Van. Turk. J. Vet. Anim. Sci., 25: 15-19.

Salihu, M.D., Junaidu, A.U., Manga, S.B., Gulumbe, M.L., Magaji, A., Ahmed, A., Adamu, A.Y, Shittu, A. and Balarabe, I. 2008. Occurrence of Listeria monocytogenes in smoked fish in Sokoto, Nigeria. African $J$. Biotechnol., 7(17): 3082-3084.

Seeliger, H.P.R., Jones, D. 1986. Genus Listeria. In: Kandler O, weiss N (Eds), regular, nonsporing Gram-positive rods. Bergey's Manual of Systematic Bacteriology, 2nd Ed. Williams and Wilkins. Baltomore. pp. 1235-1245.

Sergelus, D., A. Abraham, A. Sarmvei, C. Panoulis, P.R. Karaioannoglou and C. Genigeorge. 1997. Temperature distribution and prevalence of Listeria spp in domestic, retail and industrial refrigerators in Greece. Int. J. Food Microbiol., 34: 171-177.

Umeh, S.I., and Okpokwasili, G.S.C. 2009. Occurrence and antimicrobial profile of Listeria monocytogenes in fresh faeces of livestock animals. Nigerian J. Microbiol., 23(1):

Vazquez-Boland, J.A., Dominguez, L., Fernandez, J.F., Rodriguez-Ferri, E.F.,
Briones, V., Blanco, M. and Suarez, G. 1990. Revision of the validity of CAMP tests for Listeria identification. Proposal of an alternative method for the determination of haemolytic activity by Listeria strains. Acta Microbiol. Hung., 37: 201-206.

Wang, R.F., Cao, W.W. and Johnson, M.G. 1992. 16S rRNA-based probes and polymerase chain reaction method to detect Listeria monocytogenes cells added to foods. Appl. Environ.

Wehr, H.M. 1989. Listeria monocytogenes-A current dilemma. J. Asso. Official Anal. Chem., 70: 201-206.

Wiedmann, M. 2003. An integrated science based approach to dairy food safety. Listeria monocytogenes as a model system. J. Dairy Sci., 86: $1865-1875$.

Yakubu, Y., M.D. Salihu, O.O. Faleke, M.B. Abubakar, A.U. Junaidu, A.A. Magaji, M.L. Gulumbe, and R.M. Aliy. 2012. Prevalence and antibiotic susceptibility of Listeria monocytogenes in raw milk from cattle herds within Sokoto Metropolis, Nigeria. Sokoto J. Vet. Sci., 10(2): 13-17.

Yousef, A.E. and E.H. Marth. 1990. Fate of Listeria monocytogenes during the manufacture and ripening of parmesan cheese. J. Dairy Sci., 73: 3351-3356.

\section{How to cite this article:}

Oyinloye, Josiah Mofoluwaso Adedeji. 2016. Detection and Molecular Characterization of Listeria species in 'Wara', A West African Local Cheese Sold in Ekiti State. Int.J.Curr.Microbiol.App.Sci. 5(6): 941-948. doi: http://dx.doi.org/10.20546/ijcmas.2016.506.101 